\title{
INVESTIGATING FRAUD RISKS ASSESSMENT PRACTICES IN PUBLIC SECTOR AUDITS
}

\author{
Mohamad Mahsun ${ }^{1}$, Nafsiah Mohamed ${ }^{2}$, \\ Sharifah Norzehan Syed Yusuf ${ }^{3^{*}}$ and Indrawati Yuhertiana ${ }^{4}$ \\ ${ }^{1}$ Accounting Department, STIE Widya Wiwaha, Indonesia. \\ ${ }^{2}$ Accounting Research Institute (HICoE), Universiti Teknologi MARA, Malaysia. \\ ${ }^{3}$ Accounting Research Institute (HICoE), Universiti Teknologi MARA, Malaysia. \\ ${ }^{4}$ Fakultas Ekonomi dan Bisnis, \\ Universitas Pembangunan Nasional "Veteran" Jatim, Indonesia.
}

\begin{abstract}
Fraud Risk Assessment (FRA) is claimed to be an important activity at the audit planning stage in both the private and public sectors. In fact, because of the importance of FRA activities, Auditing Standards (SAS 99, ISA 240, ISSAI 1240) have required auditors to carry out FRAs at the audit planning stage. FRA is considered as the core activity of financial audit planning because of the impact of fraud on the sustainability of an entity, quality of life, and economic growth. This study aimed to determine the practice of FRA in public sector audits and to find out more about the obstacles faced by auditors during the audit process and to find out the causes of these obstacles by considering the approach to the Audit Standards used. This study found that auditors' performance can be determined based on their complete compliance with audit standards. We have encountered a serious problem that requires firm action from the government or a competent official, namely the auditor's willingness in preparing the Fraud Risk Assessment Matrix. In addition, we recommend the Audit Standards Board to adopt international public sector auditing standards and disseminate them through training for auditors, students, and professionals.
\end{abstract}

Keywords: fraud risk assessment, public sector audit, auditor competency

ARTICLE INFO

Article History:

Received: 2 February 2021

Accepted: 19 March 2021

Published: 30 April 2021

- Corresponding Author: Sharifah Norzehan Syed Yusuf. E-mail: shari893@uitm.edu.my 


\section{INTRODUCTION}

Fraud Risk Assessment can be considered as a core activity in all types of audits (Rehman \& Hashim, 2020) both in private and public sector accounting because fraud perpetrators can come from both internal and external (Tomaš \& Todorović, 2016) and also due to the impact of fraud on the sustainability of the entity (Mwangi \& Ndegwa, 2020), quality of life (Whitehill, 2017) and economic growth (Simbolon et al., 2019). Several factors that can influence individuals to commit fraud are: motive, ability, opportunity, and justification (Tomaš \& Todorović, 2016). Other researchers state that the factors that cause fraud and corruption are culture management, and control (Lin et al., 2015). A problem that academics, auditors, and the government rarely look at is the detection of collectivism or hidden networks (Lin et al., 2015) which negotiate in secret with an implicit intention (Duh et al., 2020; Yu et al., 2020).

Given that fraud can have an impact on business processes, performance, and can even lead to company failure (Said et al., 2018; Tomaš \& Todorović, 2016; Zahari et al., 2020), a company in addition to needing an anti-fraud system, must also have the competence to address fraud in terms of policy, management, fraud schemes, and elements of fraud. To achieve this, an auditor is required to implement a comprehensive Fraud Risk Assessment methodology in accordance with applicable standards both internationally and nationally.

Auditors contribute to the credibility of financial statements (Ismail et al., 2019). Competence, prudence, and commitment to audit quality are general requirements that auditors must have (Marsely, 2020). Auditors who have more knowledge, skills, and services are thought to be able to carry out better audits despite experiencing obstacles and time constraints. This shows that the development of auditors' competence is an important step considering that public sector auditors will encounter auditee core businesses that vary widely from one another, and which clearly requires a different format for financial statements from one auditee to another.

These comprehensive competencies implicitly require auditors to develop themselves and understand how to prevent fraud, understand indicators of fraud that are outside internal control, and other factors that 
cause fraud originating from the external environment. In this case, the auditor does not always develop a response and reporting plan that can help the institution develop the business. Therefore, this study tried to examine financial audit standards in Indonesia and understand Fraud Risk Assessment practices among auditors.

The problem examined in this study is the practice of FRA based on the results of interviews with public sector practitioners / auditors. More specifically, this study examined whether the implementation of FRA is in accordance with audit standards. We wanted to find out whether compliance with standards can improve auditor performance. In addition, this study aimed to determine the obstacles they faced during the audit process and find out the causes of these obstacles by considering the approach to the Audit Standards used. Basically, this study departs from the assumption that an obstacle in the audit process occurs due to Audit Standards that do not meet the needs of auditing practices or vice versa and the competence of auditors that needs to be improved. Through interviews, we tried to find out what competencies public sector auditors should develop.

This study looks at the obstacles faced by auditors in carrying out their duties as professionals. This study departs from the assumption that auditors who apply the State Financial Audit Standards perfectly / completely can carry out more comprehensive audits than auditors who do not apply national financial audit standards perfectly. This study also assumes that government agencies are public sector institutions. Apart from criticisms in auditing practices, this study also emphasized the selection of a sample of public sector auditors. We also explored and found out why auditors cannot properly apply auditing standards.

This research suggests that auditors develop their own competence by studying various existing standards and following trainings. In addition, the audit training institute should be aware of the weaknesses of professionalism that occurs in Indonesia so that the training institute can compile a curriculum that meets market needs, especially in cases when prospective auditors do not know and not have sufficient prior experience. This research makes another contribution to the Audit Standards Board in improving existing standards and contributing to the government in setting audit-related regulations. 


\section{LITERATURE REVIEW}

\section{Accounting Standard on Public Sector}

The Supreme Audit Board of the Republic of Indonesia (SAB RI) has established financial audit standards, namely: State Financial Audit Standards (SPKN-Standar Pemeriksaan Keuangan Negara) and Audit Management Guidelines (PMP-Panduan Manajemen Pemeriksaan). SPKN and PMP are still general in form and require implementation instructions (Juklak) so that they can be practiced uniformly (Tumija \& Febriansyah, 2019). These instructions are contained in JUKLAK Number 04 / K / I-XIII. $2 / 5 / 2008$. The audit methodology in the applicable audit standards in Indonesia consists of three stages, namely: examination, planning, and reporting of the results of the examination. Auditors are considered successful in financial audits if they meet the performance measures contained in the SPKN, PMP, and Assignment Expectations.

SPKN states that an audit of financial statements must be well planned. The implementation of the inspection plan aims to prepare the Audit Program and Steps which are the basis for the examination so that an examination can run effectively. The planning of the examination consists of 10 steps, namely: 1) Understanding the Objectives of the Examination and the Expectations of the Assignment; 2) Fulfilling the Needs of Examiners; 3) Understanding of the Entity; 4) Monitoring of the Follow-Up of Previous Examination Results; 5) Understanding of the Internal Control System; 6) Risk Assessment; 7) Determination of Initial Materiality and Tolerable Errors; 8) Determination of the sampling test method; 9) Implementation of preliminary analytical procedures; and 10) Compilation of inspection programs and individual activity programs.

The 10 (ten) stages in the accounting standard may not have a significant effect on the quality of the financial statements. This happens because there are other factors such as competence (Aswar, 2020). Therefore, this study questioned the Financial Audit Standards used by the participants and asked the participants for their opinion on whether the applicable standards in Indonesia have met the needs of public accountability.

Previous research on international public sector standards has suggested the implementation of accrual-based accounting systems (Cohen 
et al., 2021; Cuadrado-Ballesteros \& Bisogno, 2021) and International Public Sector Accounting Standards (IPSAS) (Cuadrado-Ballesteros \& Bisogno, 2021) along with the evolving needs of the entity (Cohen et al., 2021). This occurs because the traditional governance system is insufficient to meet the needs of the business environment, industry, and the complexity of risks (Brown et al., 2009). The results of these studies support Muraina and Dandago (2020) which states that accrual information can increase the level of accountability of a financial report.

\section{Fraud Risk Assessment (FRA)}

FRA is used to deal with the risk of fraud, its impact, the potential for fraud (Rehman \& Hashim, 2020). FRA is associated with increased control against potential fraud schemes, corruption, and internal and external fraud. FRA consists of the process of: identifying the risks of fraud, assessing the inherent risks of fraud, and identifying efforts to mitigate / reduce these risks in the internal control structure, evaluate the adequacy of these structures, then test the results of the evaluation (Cascarino, 2012).

The implementation of FRA in practice depends on several factors and elements that are measured based on the scale of the event / level of frequency and their impact on the organization. To achieve an effective FRA, there are several factors (as listed in table 1) that must be understood based on context (Rehman \& Hashim, 2020; Singleton \& Singleton, 2010). Effective FRA implementation can minimize financial losses due to fraud, reduce handling costs for fraud, increase entity compliance with regulations, increase employee awareness, and produce more preferential governance of entities (Abdullatif, 2013; Mansor, 2015; Rehman \& Hashim, 2020).

Table 1: Factor of Effective FRA

\begin{tabular}{ll}
\hline \multicolumn{1}{c}{ Factors } & \multicolumn{1}{c}{ Description } \\
\hline Internal Factor & $\begin{array}{l}\text { Everyone and everything (such as payroll system) in } \\
\text { an organization are more susceptible to fraud } \\
\text { All factors that allow the fraud scheme to occur }\end{array}$ \\
$\begin{array}{l}\text { Fraud Factor } \\
\text { Corporate environment }\end{array}$ & $\begin{array}{l}\text { Some industries have a business environment that is } \\
\text { more susceptible to fraud and requires control of the } \\
\text { potential for fraud }\end{array}$ \\
\hline
\end{tabular}

Source: (Rehman \& Hashim, 2020; Singleton \& Singleton, 2010; Yusuf et al., 2020) 
Anti-Fraud can be realized effectively when management has the commitment to implement it (Mwangi \& Ndegwa, 2020). Previous research has recommended the adoption / implementation of FRAs in governance which functions as a fraud detection and control mechanism (Rehman \& Hashim, 2020). Previous research on FRA has found that FRA has a direct and significant impact on governance (Rehman \& Hashim, 2020). Implicitly, this conclusion explains that ineffective control indicates the weak quality of governance in an entity. This inffective control is one of the causes of fraud (ACFE, 2016; Yusuf et al., 2020). In fact, fraud can only be controlled through prevention (Girgenti \& Hedley, 2011).

\section{Public Sector Accountants Competency}

Previous research has tested and supported the hypothesis which states that the higher the level of independence, objectivity and experience of the auditor, the higher the auditor's sensitivity in detecting fraud (Bimantara $\&$ Ngumar, 2018). However, in practice, accountants / auditors are not only faced with problems of knowledge and skills. Some auditors are sometimes faced with political, power, and cultural situations in carrying out their duties. So in discussing the competence of auditors in detecting fraud, apart from having to depart from the point of view of knowledge, academics must also look at the background and the situation in the field and obstacles comprehensively.

Table 2: Previous Research on Competence of Public Sector Accountants

\begin{tabular}{|c|c|c|c|}
\hline Author & Country & Sample & Conclusion \\
\hline $\begin{array}{l}\text { Popoola et al. } \\
\text { (2014) }\end{array}$ & Nigeria & 422 & $\begin{array}{l}\text { Forensic accountants significantly have } \\
\text { higher knowledge level, skills, and task } \\
\text { performance fraud risk assessment about } \\
\text { fraud preventation, detection, and response. }\end{array}$ \\
\hline $\begin{array}{l}\text { Kiswanto \& } \\
\text { Maulana (2019) }\end{array}$ & Indonesia & 41 & $\begin{array}{l}\text { The assessment of the risk of fraud, } \\
\text { skepticism, workload, and experience } \\
\text { affects the ability of auditors to detect fraud. }\end{array}$ \\
\hline $\begin{array}{l}\text { Maresch et al. } \\
\text { (2019) }\end{array}$ & $\begin{array}{l}\text { Australia, } \\
\text { Geremany, and } \\
\text { unspecified } \\
\text { country }\end{array}$ & $\begin{array}{c}149 \\
\text { (auditor) } \\
\text { and } 116 \\
\text { (CFOs) }\end{array}$ & $\begin{array}{l}\text { Both auditors and Chief Financial Officers } \\
\text { (CFOs) will consider the competence of their } \\
\text { respective business partners, especially in } \\
\text { disagreement situations. Competence trust } \\
\text { is considered very important in determining } \\
\text { the outcome of negotiations. This indicates } \\
\text { the existence of a "trust-threat" from each } \\
\text { auditor and CFOs. }\end{array}$ \\
\hline
\end{tabular}




\begin{tabular}{|c|c|c|c|}
\hline Author & Country & Sample & Conclusion \\
\hline $\begin{array}{l}\text { Sucher \& } \\
\text { Kosmala- } \\
\text { MacLullich } \\
(2004)\end{array}$ & Czech & 19 & $\begin{array}{l}\text { The pressure of socio-economic and } \\
\text { cultural is greater than the security which is } \\
\text { legally applicable to maintain integrity and } \\
\text { professional competence in the Central and } \\
\text { Eastern European Economies (CEE) region. }\end{array}$ \\
\hline $\begin{array}{l}\text { Olivier et al. } \\
\text { (2019) }\end{array}$ & $\begin{array}{l}\text { Unspecified } \\
\text { (interview } \\
\text { in English, } \\
\text { French, and } \\
\text { Spanish) }\end{array}$ & 38 & $\begin{array}{l}\text { Audit standards tend to be used as a } \\
\text { means of legitimacy rather than as a } \\
\text { guide in improving quality. In addition, } \\
\text { auditors are required to provide various and } \\
\text { complex skills in providing good sustainable } \\
\text { assurance. The absence of training in this } \\
\text { matter that is substantially acknowledged in } \\
\text { this field could damage the reputation of the } \\
\text { auditing profession. }\end{array}$ \\
\hline $\begin{array}{l}\text { Ravenda et al. } \\
\text { (2018) }\end{array}$ & Italy & 224 & $\begin{array}{l}\text { Mafia Firms manages more income, } \\
\text { expense, and aggregate accruals to } \\
\text { streamline income and disguise money } \\
\text { laundering than Lawful Firms. This suggests } \\
\text { that the auditor's insight and competence } \\
\text { can influence his decision to use the } \\
\text { traditional aggregate accrual model that } \\
\text { cannot fully detect money laundering. }\end{array}$ \\
\hline
\end{tabular}

Inspired by previous research, we compiled the competencies that auditors must have based on the type of fraud. Table 3 shows the types of fraud that are divided into: 1) misstatement resulting from the misappropriation of assets (intentionally committing fraud against assets). 2). Misstatement resulting from fraudulent financial reporting (intentionally committing fraud in financial reports).

Table 3: Competence Framework in Fraud Risk Assessment

\begin{tabular}{lll}
\hline \multicolumn{1}{c}{ Type of Fraud } & Competence Requirements & \multicolumn{1}{c}{ Derrived from } \\
\hline Misstatements & Forensic Accounting & (Ahmad et al., 2013; Popoola et al., \\
result from the \\
misappropria tion $\begin{array}{l}\text { 2014; Verwey \& Asare, 2016) } \\
\text { of assets }\end{array}$
\end{tabular}




\begin{tabular}{|c|c|c|}
\hline Type of Fraud & Competence Requirements & Derrived from \\
\hline \multirow{7}{*}{$\begin{array}{l}\text { Misstatement } \\
\text { result from } \\
\text { fraudulent } \\
\text { financial reporting }\end{array}$} & $\begin{array}{l}\text { Fulfilling the ethical code and } \\
\text { professionalism }\end{array}$ & $\begin{array}{l}\text { (Ali et al., 2020; Fatt, 1995; Lai et al., } \\
\text { 2018) }\end{array}$ \\
\hline & $\begin{array}{l}\text { Evaluate uncertainty of } \\
\text { company's business process }\end{array}$ & $\begin{array}{l}\text { (Davies \& Aston, 2011; Gibbins et al., } \\
\text { 2001; Paino et al., 2014; Pedrosa \& } \\
\text { López-Corrales, 2018) }\end{array}$ \\
\hline & $\begin{array}{l}\text { Disclose the transparency of } \\
\text { financial statements }\end{array}$ & $\begin{array}{l}\text { (Legoria et al., 2018; Muñoz-Izquierdo } \\
\text { et al., 2019) }\end{array}$ \\
\hline & $\begin{array}{l}\text { Compliance with audit } \\
\text { standard }\end{array}$ & $\begin{array}{l}\text { (Harahap et al., 2017; Melé, 2005; } \\
\text { Rachmadia et al., 2020; Veiga, 2004) }\end{array}$ \\
\hline & $\begin{array}{l}\text { Giving the best quality of } \\
\text { audit }\end{array}$ & $\begin{array}{l}\text { (DeAngelo, 1981; Harahap et al., } \\
\text { 2017) }\end{array}$ \\
\hline & Reduce conflict & (Pham et al., 2020) \\
\hline & $\begin{array}{l}\text { Reduce earnings } \\
\text { management risks }\end{array}$ & $\begin{array}{l}\text { (Almarayeh et al., 2020; Chae et al., } \\
\text { 2020; Cohen et al., 2008) }\end{array}$ \\
\hline
\end{tabular}

\section{RESEARCH METHOD}

\section{Participant and Data Collection}

This study was conducted by means of in-depth interviews with 7 public sector auditors from the Supreme Audit Board of Republic of Indonesia. We also held a focus group discussion (FGD) with auditors from the Supreme Audit Board of Indonesia through direct questions and was developed freely which had been planned before the interview. The data collected were in the form of audio recordings and resume of interview. A data management software, the Nvivo Software Version 12 was used to manage the processed data made by the researcher. The focus of this discussion was to find out about the standards used by auditors, obstacles in implementing Fraud Risk Assessment, and knowing the skills that must be developed by auditors.

\section{Other Methodological Issues}

In-depth interviews and FGDs were conducted in Indonesian. Then we rearranged the grammar so that it can be translated into English according to English grammar. This was done because some of the sentences uttered by the participants could not be understood if they were translated into English directly. 


\section{FINDINGS}

Among auditors, many people are still biased about their duties and responsibilities. Based on our interview excerpts, (P7) said:

"We may experience bias when comparing what the BPK did and what the KPK did. BPK is in a "preventive" and not "repressive" position within its institutional constellation and functions. Preventive means that "what we do and produce is an input" The input is not necessarily considered to be a fraud. The input may still be an indication of fraud, or it could be fraud, but it still cannot be further processed (because the $B P K$ does not have a high authority), for example, 'confiscate, investigate, detain. Indeed, the BPK does not have the authority to confiscate documents until the position when it is already entering the realm of 'predication,' which is clearly (certain) fraud, has occurred (P7).

In summary, we found that, all of our participants used the SPKN as a guide in conducting audits. In SPKN, auditors are required to prepare a Fraud Risk Assessment Matrix (FRAM).

In the audit planning stage, fraud risk assessment is carried out by preparing Fraud Risk Assessment Matrix (FRAM). FRA is conducted by preparation of working papers based on FRAM supported by relevant, sufficient and competent evidence. (P2)

We are giving an assessment which is called FRAM. We tend to understand it as "how we are careful and how we anticipate that we face 3 risks" (business risks in auditing start from control risk, our audit risk, and auditors' business risk). So FRAM is compiled during "planning". This becomes a guidence for auditors to map the risks of fraud. To map it, we need to know what frauds must be tested whether it is related to the procurement of goods and services, is it related to employment, is it related to matters relating to cash, is it related to corruption, or other forms related to "creation", Embezzlement, or related to fraud in the form of financial reporting. (P7) 
"The FRA is carried out in accordance with the Technical Guidelines for risk assessment in the form of a Fraud Risk Assessment Matrix (FRAM)." (P5)

Implementation of the FRA at the planning stage, precisely at the stage of understanding entities and business processes. (P4)

However, one of our participants admitted that the preparation of FRAM was a challenging and difficult activity to carry out. This indicates that not all auditors are able to prepare FRAM properly and effectively even though they have worked as public sector auditors for a long time. Interestingly, one of our participants stated that an auditor who deliberately does not prepare a FRAM can be certain that he plans to fail (audit failure).

My opinion about FRAM is "if the auditor deliberately does not do FRAM then the auditor plans to fail (audit failure)." This meant that he was being careless from the start. (P7)

\section{Audit Standard Used by Participant}

Based on interviews and FGDs, our participants mentioned several standards including: SPKN, SPAP (Public Accoutant Professional Standards), ISSAI 1240, and ISA 240. It seems that our participants tend to use SPKN as "default guidance". Basically, SPKN is complete enough to be used as a basis for financial audits because it contains the standards of the public accounting profession that is applied in Indonesia. In fact, SPKN has been developed into Jukla (Implementation Guidance) and Juknis (Technical Materiality) which can make it easier for auditors to learn.

In the SPKN, we have drawn (quoted) all the provisions contained in ISA 24. This is based on the conceptual framework which states that the SPKN-especially regarding financial auditing - applies professional standards established by IAPI (Indonesian Institute of Certified Public Accountants). The professional standard is SPAP (Public Accountant Professional Standards). Thus, all SA (Audit Standards) are applied in the SPKN. so the examination of LKPD (Regional Government Financial Statements) has enforced all SPAP. (P6) 
SPKN has accommodated the issues regarding fraud which were later described in the Implementation Guidelines (Jukla), then reduced (explained) again to become "sharing guidelines". "Guidelines" are more detailed explanations but are more concise in explaining the "standards". while "Juknis" has discussed what the substance is. For example: when we discuss materiality, we can look at the "technical materiality" (JukNis). (P6)

We can say that in SPKN and of course in all auditing standards, especially in auditing standards on finance, the objective of a financial audit is a financial audit which aims to produce an opinion through testing and assessing the fairness of an institution's financial statements (P6). It has been stated in the "objective financial audit" that the BPK's (SAB's) duties include examining material misstatements due to fraud. However, based on ISA 240 which has been ratified as ISSAI 1240, it is stated (in ISA 240) paragraph 2 that: fraud is truly anti-legal concept and the auditor has no burden or no authority to ensure that fraud is occure. (P6)

\section{Obstacles in Auditing Practice}

Time budget / time pressure and competence in dealing with various cases seem to be indications of audit failure. However, a job is declared complete when the job has actually been completed and is not forced to be considered finished. Based on the interviews we conducted, the auditors experienced a number of obstacles. We grouped the barriers under the theme: a) Budget b) Competence: (knowledge and experience) c) Pressure of time.

Constraints in implementing the FRA are:1). Auditor resources in terms of numbers and abilities 2). Short inspection time, 3). Limited budget allocation. (P2)

Our respondents also complained of "time pressure" They must plan, implement and respond within 2 months for 1 year of financial reporting. Time problems are more frequent when auditors decide to go deeper to prove fraud. 
Time: Mr. Mahsun can already feel for himself how time constraints limit us (auditors). Maybe from our side (auditors), we (auditors) can better prepare it because this is our job with all its uniqueness. However, when the position of other people is directly involved in a certain field, there will definitely be a lot to be handled (do, think, and test). meanwhile we deal more with the most urgent and big risks. So that "Risk Base Audit" becomes the most profitable solution for us to be able to test everything (P7).

Obstacles-time: Obstacles in the audit process are time and input. next is human resource constraints. Not all of our human resources have an accountant education background. We come from various disciplines (P7). it takes more time to work on 2 tasks at a time. (P4)

Obstacles-time: When the auditor has decided to go deeper, then he must determine: 1. Nature, 2. Time, 3. the context of the scope (context of the audits). These three things are the auditor's overall response. hence I would like to say that "FRAM may be initiated to be held early in the audit process. The audit attitude towards risk is 3 stages (identify, asses, respond). It is an iterative process. Even at the reporting stage this attitude will take place. auditors have different ways. The results of each auditor's assessment are different, depending on how the auditor responds. In RBA (Business Plan and Budget), risk management always involves these 3 main processes (identification, assessment, response). (P6)

Obstacles-Competence (willingness): Another challenge as an auditor is preparing a working paper. sorry if $i$ have to convey it. (P6) The FRA Guidance is enough, if problems arise usually related to the willingness of the auditor who accustomed himself to never making FRAM. (P4)

Obstacles-Budget: Moh Mahsun: So if we do a resume, the obstacles in conducting an investigative audit are: human resources and budget constraints, right? (P5): Yes 
The auditors interviewed admitted that there were obstacles related to budgets for developing human resource competence. Three (3) out of seven (7) respondents agreed that knowledge and experience can affect the performance of an auditor. The reason is, not all auditors have relevant educational background. Thus, many feel uncomfortable in implementing the FRA Matrix (FRAM). Therefore, one of them took the initiative to develop human resources and budgeted funds for training. On the other hand, some of our respondents stated that they did not feel any effort from other Government Agencies to audit them. So some of them do not feel controlled in terms of FRAM arrangement. Others stated that, if the auditors deliberately did not prepare FRAM, then they had planned to fail in the audit (audit failure).

\section{Table 4: Participant's Confirmation About \\ Obstacles During The Audit Process}

\begin{tabular}{lcccll}
\hline $\begin{array}{c}\text { Interviewee } \\
\text { Code }\end{array}$ & Budget & Competence & $\begin{array}{c}\text { Time } \\
\text { Pressure }\end{array}$ & Experience & Position \\
\hline P1 & & $\checkmark$ & & 9 Years & Junior Auditor \\
P2 & $\checkmark$ & $\checkmark$ & $\checkmark$ & 17 Years & Senior Auditor \\
P3 & & $\checkmark$ & & 28 Years & Senior Auditor \\
P4 & $\checkmark$ & $\checkmark$ & 13 Years & Auditor Trainer and \\
P5 & & & & 18 Years & Senior Auditor \\
P6 & $\checkmark$ & $\checkmark$ & 12 Years & Senior Auditor \\
P7 & $\checkmark$ & $\checkmark$ & 18 Years & Chairman \\
\hline
\end{tabular}

\section{Urgency of Developing Auditors Competencies}

Competence in detecting fraud and preventing fraud must be possessed by every auditor. Auditors are required to follow scientific developments and explore the field of forensic accounting.

Urgency of developing competence: What I need to say is that the phenomenon of fraud is like an iceberg. what is seen in the eyes of ordinary people is onl y a little, but in fact there could be a lot of melting ice, it could be a little. well this is indeed a challenge for us as auditors to prove how big something is based on its "small" appearance. How to prove how material 
or a transaction is based solely on analysis of available data. I admit, this requires competence and experience. maybe that's what I can say sir. (P7)

I would like to add that the way to reduce must go through several more stages. can we identify the case? yes we cen. can we asses the risk? yes we can. but all of that is a detection. When we run a test and conduct a field investigation, we may not find any fraud. (P6)

The main obstacle is human resources. Our auditors do not have a background (backgroud) of auditor education such as BPKP and BPK. Our human resources come from several UPTs with various backgrounds who are not auditors. This affects their understanding of what is called an investigative audit. Besides, the budget to improve auditor competence is very limited. So this makes us overwhelmed in carrying out the investigation (ideally and optimally). (P5)

The main obstacle in implementing FRA is that the auditor's level of understanding is still lacking in the substance of the FRA and its techniques are still unclear. (P1)

Although the quote above shows that the participants are talking about obstacles, basically the obstacles discussed are auditor competence. The quote above illustrates that not all auditors have the skills needed as professionals. In addition, there are many other skills that must be developed such as conducting forensing account; detecting fraud; dealing with various pressures including time budget, socio-economic, political, and cultural; fulfilling the ethical code and professionalism, reducing conflict of interest and earnings management risk; and compliance with audit standards.

\section{DISCUSSION}

The auditor may be faced with situations that they have never experienced before. The auditor may encounter a situation where he has to make a decision but is not authorized to do so. Most auditors work in groups. 
However, the response of a group to a problem may be influenced by the response of each individual in a team.

I have explained earlier that there are 3 things that affect the "response" of an auditor like me. First) competence, second) experience, third) knowledge and implementation of the code of ethics (integrity). (P6)

Integrity: When I have a judgment on something, my judgment will be verified by his judgment. Of course, his gudgement will be accepted based on his competence. Why is that? is there any particular experience that becomes evidence? so he replied: I have audited the KPK 10 times. (P6)

If the standard board considers that the standards issued are sufficient for the needs of auditors, then the relevant implication (according to the theme of this study) is: "the standard board must develop / prepare guidance in more detail". This is in accordance with the opinion of (P3):

FRAM has not been enough to assist auditors in implementing FRA. There is a need to guide the preparation of FRAM as a detailed procedure. (P3)

On the other hand, the SAB RI pays less attention to this problem with evidence of the absence of follow-up from the SAB RI on this issue. P3 states:

Lack of awareness from BPK RI members (ministry level) regarding the importance of FRAM testing in accordance with audit standard of state finance and international audit standards. (P3)

However, there are differences of opinions / contradictions among our participants. P4 and $\mathbf{P 2}$ said:

The FRA Guidance is enough, if problems arise usually related to the willingness of the auditor who accustomed himself to never making FRAM. (P4) 


\section{LIMITATION AND FUTURE RESEARCH}

To find out the barriers that are outside the standard, it is necessary to have participants from the auditee and case studies on the confusion between the applicable laws / standards and field conditions. In addition, maybe this research still requires other evidence such as what competencies a fresh graduate has so that we can find out the comparisons / comparisons of competences between professionals and fresh graduates.

We recommend further research to find out how to develop the competence of auditors and prospective auditors and focus on knowing what steps must be taken by the audit standards board in improving the circulated standards.

\section{IMPLICATION}

The implication of the findings of this study is the development of curriculum training institutes that meet market needs, especially in cases when prospective auditors do not know and have sufficient prior experience.

\section{CONCLUSION}

Fraud can never be stopped. As an auditor, the main role in overcoming fraud is preventive measures. In order to prevent fraud effectively, auditors are required to be able to prepare a Fraud Risk Assessment in accordance with applicable standards. Although in practice auditors face time pressure situations and a weak budget, auditors are believed to be able to complete their duties as long as they have the required competencies. This argument shows that, no matter how heavy the pressure is, and wherever the pressure comes from, auditors only need to continuously develop their own competence. We suspect that auditors who meet audit standards in practice have achieved good performance. Although at first we suspected that the audit standards did not meet auditors 'needs, our participants stated that the existing standards were sufficient for the auditors' knowledge needs. 
Furthermore, the problem of audit failure actually arises from the auditors' willingness in preparing FRA. Therefore, apart from the need for firm action on this negligence, the audit standards board also needs to accommodate all international public sector accounting standards and hold training and human resource development for both public and private sector auditors.

\section{ACKNOWLEDGEMENT}

The authors would like to acknowledge the assistance from the Ministry of Higher Education for HICoE research funding, Accounting Research Institute, Universiti Teknologi MARA, Malaysia for all supports and resources.

\section{REFERENCE}

Abdullatif, M. (2013). Fraud risk factors and audit programme modifications: Evidence from Jordan. Australasian Accounting, Business and Finance Journal, 7(1), 59-77.

ACFE. (2016). Fraud prevention and deterrence. ACFE Association of Certified Fraud Examinerson.

Ahmad, A. C., Popoola, O. M. J., Samsudin, R. S., \& Ahmad, H. (2013). An examination of task performance fraud risk assessment on forensic accountant knowledge and mindset in Nigerian public sector. Paper presented at the International Conference on Business and Social Science (ICBASS) 2013, Seoul, South Korea. Retrieved from https:// core.ac.uk/download/pdf/42982779.pdf

Ali, W., Ali, S., \& Khalid, Z. (2020). Comparison of ethical reasoning between accounting student and auditors. Global Management Journal for Academic \& Corporate Studies, 10(1), 94-105.

Almarayeh, T. S., Aibar-Guzmán, B., \& Abdullatif, M. (2020). Does audit quality influence earnings management in emerging markets? Evidence from Jordan. Revista de Contabilidad-Spanish Accounting Review, 23(1), 64-74. 
Aswar, K. (2020). Assessing the impact of influencing factors on the quality of local government financial statements. Pressacademia, 7(1), 1-8.

Bimantara, R. B., \& Ngumar, S. (2018). Pengaruh independensi, objektivitas, dan pengalaman pemeriksa terhadap pendeteksian kecurangan. Jurnal Ilmu Dan Riset Akuntansi, 7(5), 1-18.

Boiral, O., Heras-Saizarbitoria, I., \& Brotherton, M. C. (2019). Professionalizing the assurance of sustainability reports: The auditors' perspective. Accounting, Auditing and Accountability Journal, 33(2), 309-334.

Broberg, P., Tagesson, T., Argento, D., Gyllengahm, N., \& Mårtensson, O. (2017). Explaining the influence of time budget pressure on audit quality in Sweden. Journal of Management and Governance, 21(2), 331-350.

Brown, I., Steen, A., \& Foreman, J. (2009). Risk management in corporate governance: A review and proposal. Corporate Governance: An International Review, 17(5), 546-558.

Cascarino, R. E. (2012). Corporate fraud and internal control: A framework for prevention. New Jersey: John Wiley \& Sons.

Chae, S.-J., Nakano, M., \& Fujitani, R. (2020). Financial reporting opacity, audit quality and crash risk: Evidence from Japan. The Journal of Asian Finance, Economics, and Business, 7(1), 9-17.

Cohen, D. A., Dey, A., \& Lys, T. Z. (2008). Real and accrual-based earnings management in the pre-and post-Sarbanes-Oxley periods. The Accounting Review, 83(3), 757-787.

Cohen, S., Rossi, F. M., Caperchione, E., \& Brusca, I. (2021). Debate: If not now, then when? Covid-19 as an accelerator for public sector accrual accounting in Europe. Public Money \& Management, 41(1), 10-12.

Cuadrado-Ballesteros, B., \& Bisogno, M. (2021). Public sector accounting reforms and the quality of governance. Public Money \& Management, $41(2), 107-117$. 
Davies, M., \& Aston, J. (2011). Auditing fundamentals. Harlow: Financial Times/Prentice Hall.

DeAngelo, L. E. (1981). Auditor size and audit quality. Journal of Accounting and Economics, 3(3), 183-199.

Duh, R.-R., Ye, C., \& Yu, L.-H. (2020). Corruption and audit market concentration: An international investigation. Asia-Pacific Journal of Accounting \& Economics, 27(3), 261-279.

Epstein, B. J., \& Ramamoorti, S. (2016). Today's fraud risk models lack personality auditing with 'dark triad' individuals in the executive ranks. CPA Journal, 86(3), 14-21.

Fatt, J. P. T. (1995). Ethics and the accountant. Journal of Business Ethics, 14(12), 997-1004.

Gaol, M. B. L., Ghozali, I., \& Fuad, F. (2017). Time budget pressure, auditor locus of control and reduced audit quality behavior. International Journal of Civil Engineering and Technology, 8(12), 268-277.

Gibbins, M., Salterio, S., \& Webb, A. (2001). Evidence about auditor - Client management negotiation concerning client's financial reporting. Journal of Accounting Research, 39(3), 535-563.

Girgenti, R. H., \& Hedley, T. P. (2011). Managing the risk of fraud and misconduct: Meeting the challenges of a global, regulated and digital environment. New York: McGraw Hill Professional.

Gundry, L. C., \& Liyanarachchi, G. A. (2007). Time budget pressure, auditors' personality type, and the incidence of reduced audit quality practices. Pacific Accounting Review, 19(2), 125-152.

Harahap, D., Suciati, N. H., Puspitasari, E., \& Rachmianty, S. (2017). Pengaruh pelaksanaan standar audit berbasis International Standards on Auditing (ISA) terhadap kualitas audit. Jurnal ASET (Akuntansi Riset), 9(1), 55-72.

Ismail, A. H., Merejok, N. M., Dangi, M. R. M., \& Saad, S. (2019). Does 
audit quality matters in Malaysian public sector auditing? Journal of Academia, 7, 102-116.

Kiswanto, F. E., \& Maulana, P. A. (2019). Pengalaman memoderasi penilaian resiko kecurangan, skeptisisme, beban kerja pada kemampuan mendeteksi kecurangan. Jurnal Ilmiah Akuntansi Dan Bisnis, 14(2), 183-195.

Lai, K. M. Y., Sasmita, A., Gul, F. A., Foo, Y. B., \& Hutchinson, M. (2018). Busy auditors, ethical behavior, and discretionary accruals quality in Malaysia. Journal of Business Ethics, 150(4), 1187-1198.

Legoria, J., Reichelt, K. J., \& Soileau, J. S. (2018). Auditors and disclosure quality: The case of major customer disclosures. Auditing: A Journal of Practice \& Theory, 37(3), 163-189.

Lin, C. C., Chiu, A. A., Huang, S. Y., \& Yen, D. C. (2015). Detecting the financial statement fraud: The analysis of the differences between data mining techniques and experts' judgments. Knowledge-Based Systems, $89,459-470$.

Lyons, M. (2019). The dark triad of personality: Narcissism, Machiavellianism, and psychopathy in everyday life. London: Academic Press.

Mansor, R. (2015). Forensic accounting and fraud risk factors: The influence of fraud diamond theory. The American Journal of Innovative Research and Applied Sciences, 7(28), 186-192.

Maresch, D., Aschauer, E., \& Fink, M. (2019). Competence trust, goodwill trust and negotiation power in auditor-client relationships. Accounting, Auditing and Accountability Journal, 33(2), 335-355.

Marsely, M. (2020). Does audit quality affect client satisfaction of non profit organization in Indonesia? Proceedings of the 1st Annual Management, Business and Economic Conference (AMBEC 2019), 136, 118-122.

Melé, D. (2005). Ethical education in accounting: Integrating rules, values and virtues. Journal of Business Ethics, 57(1), 97-109. 
Muñoz-Izquierdo, N., Segovia-Vargas, M. J., \& Pascual-Ezama, D. (2019). Explaining the causes of business failure using audit report disclosures. Journal of Business Research, 98, 403-414.

Muraina, S. A., \& Dandago, K. I. (2020). Effects of implementation of International Public Sector Accounting Standards on Nigeria's financial reporting quality. International Journal of Public Sector Management, $33(2 / 3), 323-338$.

Mwangi, S. W., \& Ndegwa, J. (2020). The influence of fraud risk management on fraud occurrence in Kenyan listed companies. International Journal of Finance \& Banking Studies, 9(4), 147-160.

Paino, H., Hadi, K. A. A., \& Tahir, W. M. M. W. (2014). Client's business risk assessment and auditor's substantive test. Procedia Economics and Finance, APRIL 2014.

Paulhus, D. L., \& Williams, K. M. (2002). The dark triad of personality: Narcissism, machiavellianism, and psychopathy. Journal of Research in Personality, 36(6), 556-563.

Pedrosa, M. A., \& López-Corrales, F. (2018). Auditors' response to the global financial crisis: Evidence from Spanish non-listed companies. Spanish Journal of Finance and Accounting, 47(3), 400-431.

Pham, C. B., Vu, T. M., Nguyen, L. H., \& Nguyen, D. D. (2020). Audit quality and stock return co-movement: Evidence from Vietnam. The Journal of Asian Finance, Economics, and Business, 7(7), 139-147.

Popoola, O. M. J., Che-Ahmad, A., \& Samsudin, R. S. (2015, February). Forensic accountant and auditor knowledge and skills requirements for task performance fraud risk assessment in the Nigerian public sector. Paper presented at the International Conference on Accounting Studies (ICAS, 2015).

Rachmadia, F., Askandar, N. S., \& Afifudin, A. (2020). Pengaruh implementasi audit berbasis internasional standards on auditing terhadap kualitas auditing. Jurnal Ilmiah Riset Akuntansi, 09(01), 43-52. 
Ravenda, D., Valencia-Silva, M. M., Argiles-Bosch, J. M., \& GarciaBlandon, J. (2018). Accrual management as an indication of money laundering through legally registered Mafia firms in Italy. Accounting, Auditing and Accountability Journal, 31(1), 286-317.

Rehman, A., \& Hashim, F. (2020). Impact of fraud risk assessment on good corporate governance: Case of public listed companies in Oman. Business Systems Research, 11(1), 16-30.

Said, J., Asry, S., Rafidi, M., Obaid, R. R., \& Alam, M. M. (2018). Integrating religiosity into fraud triangle theory: Empirical findings from enforcement officers. Global Journal Al-Thaqafah, 2018(S), 131-143.

Said, L. L., \& Munandar, A. (2018). The influence of auditor's professional skepticism and competence on fraud detection: The role of time budget pressure. Jurnal Akuntansi Dan Keuangan Indonesia, 15(1), 104-120.

Sayed Hussin, S. A. H., Iskandar, T. M., Saleh, N. M., \& Jaffar, R. (2017). Professional skepticism and auditors' assessment of misstatement risks: The moderating effect of experience and time budget pressure. Economics and Sociology, 10(4), 225-250.

Simbolon, R., Ahmad, N., \& Elviani, S. (2019). Are the model of fraud triangle elements sufficient enough to prevent fraud?: Evidence in North Sumatra Province. In 1st International Conference on Social Sciences and Interdisciplinary Studies (ICSSIS 2018) (pp. 356-359). Atlantis Press.

Singleton, T. W., \& Singleton, A. J. (2010). Fraud auditing and forensic accounting $\left(4^{\text {th }}\right.$ ed). Hoboken, N.J: John Wiley \& Sons, Inc.

Sucher, P., \& Kosmala-MacLullich, K. (2004). A construction of auditor independence in the Czech Republic: Local insights. Accounting, Auditing \& Accountability Journal, 17(2), 276-305.

Sulistyowati, L., \& Supriyati, S. (2016). The effect of experience, competence, independence, and professionalism of auditors on fraud detection. The Indonesian Accounting Review, 5(1), 95-110. 
Tomaš, D., \& Todorović, I. (2016). Modelling fraud prevention process. European Journal of Economics and Management, 3(2), 90-107.

Tumija, T., \& Febriansyah, M.A. (2019). Implementasi standar pemeriksaan keuangan negara (SPKN) 2017 dalam pelaksanaan pemeriksaan keuangan oleh badan pemeriksa keuangan Republik Indonesia. TRANSFORMASI: Jurnal Manajemen Pemerintahan, 11(1), 73-86.

Umar, H., Erlina, E., Fauziah, A., \& Purba, R. B. (2019). Audit quality determinants and the relation of fraud detection. International Journal of Civil Engineering and Technology, 10(3), 1447-1460.

Veiga, J. F. (2004). Bringing ethics into the mainstream: An introduction to the special topic. Academy of Management Perspectives, 18(2), 37-38.

Verwey, I., \& Asare, S. K. (2016). The effect of forensic expertise and time pressure on fraud risk assessment and responsiveness. SSRN Electronic Journal 2864350.

Whitehill, C. C. (2017). The financial cost of fraud: The latest data from around the world. 1-14.

Yanti, L., Darwanis, Abdullah, S., \& Djalil, M. A. (2017). Influence of competence, professional skeptism and audit knowledge on financial decrease detection (Study on Inspectorate Aceh). BRAND. Broad Research in Accounting, Negotiation, and Distribution, 9(2), 13-21.

Yu, K.-H., Kang, S.-D., \& Rhodes, C. (2020). The partial organization of networked corruption. Business \& Society, 59(7), 1377-1409.

Yusuf, Z., Nawawi, A., \& Salin, A. S. A. P. (2020). The effectiveness of payroll system in the public sector to prevent fraud. Journal of Financial Crime.

Zahari, A. I., Said, J., \& Arshad, R. (2020). Organisational fraud: A discussion on the theoretical perspectives and dimensions. Journal of Financial Crime, 27(1), 283-293. 